\title{
ON THE LANGUAJE AND STYLE OF EUPHORION OF CHALCIS
}

Many textual and interpretative problems presented by the fragments of Euphorion can be solved if we study them within the framework of the canons governing Hellenistic poetic composition.

In this article I shall discuss various textual and interpretative problems which are presented to us by the fragments of Euphorion of Chalcis. For the convenience of the reader I print van Groningen's text '.

Fr. $2(=A . P$. VII 651$)$ :

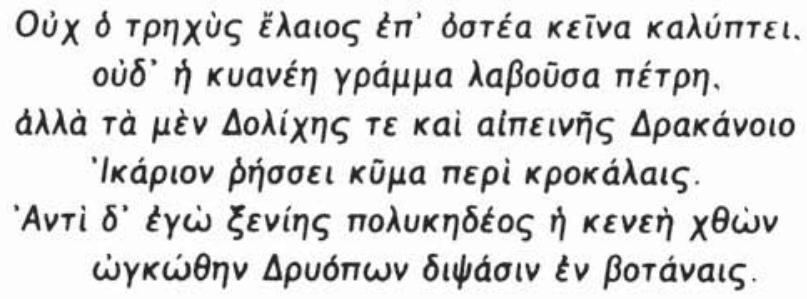

Translation by W. R. Paton (The (ireek Anthologr! Loch edition, London 1970, reprint, vol. 2, p. 349): "(raggy Elacus doth not cover those thy bones, nor this stone that speaks in blue letters. They are broken by the Icarian seat on the shingly beach of Doliche and lofty Dracanon, and I, this empty mound of earth, am heaped up here in the thirsty herbage of the Dryopes for the sake of old friendship with Polymedes."

In line $2 \mathrm{v}$. Groningen printed the alteration кuavé rather than the

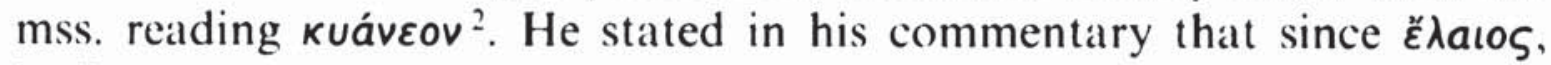

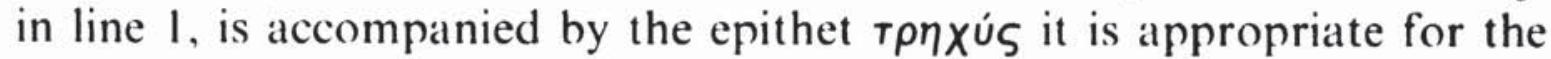
noun пв́тр $\eta$, in line 2 , also to have an epithet. Textual alteration is nevertheless not warranted.

${ }^{1}$ Cf. B. A. v. Groningen, Euphorion, Amsterdam 1977. Cf. moreover the excellent edition and commentary by L. A. de ('uenca (Euforión de ('alcis, Madrid 1976).

2 De Cuenca correctly retained the mss. reading kuáveov: cf. op. cit., p. 331. 
V. Groningen has overlooked the fact that structural inconcinnitas was much favoured by Hellenistic poets: cf. my Studies In Theocritus And Other Hellenistic Poets, Amsterdam 1979, p. 38 and my Studies In The Poetry of Nicander, Amsterdam 1987, p. 97, note 1: "disbalance... is a favourite trick of Nicander's». Cf. moreover Euphorion fr. 63 where $\varepsilon^{\prime} v \kappa v \eta \dot{\mu} \mu \eta \iota v$ follows the dative $\Sigma(\theta o v i \eta$.

Fr. 4

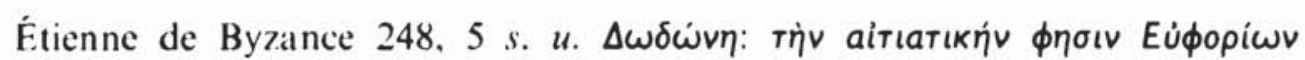
$\Delta \omega \delta \tilde{\omega} v a z^{\prime} v^{\prime}$ Avi $\omega^{\prime}$.

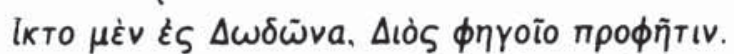

Julien Or. 4 p. 149 B. (repris par Eustathe In Iliad. 83, 44): каi тойто ठغ் aútò

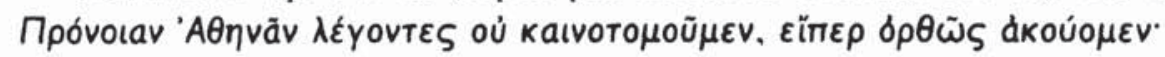

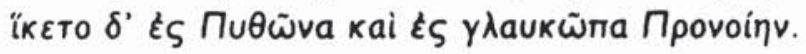

In his commentary on the words Iкто... їкєто, v. Groningen noted that the poet has purposely varied the form of the verb. For other examples of morphological inconcinnitas of. my Essays in Hellenistic Poetry, Amsterdam 1980, p. 42, note 1, and F. Lapp, De Callimachi Cyrenaei Tropis Et Figuris, Diss. Bonn 1965, p. 125 ff.

Fr. 6

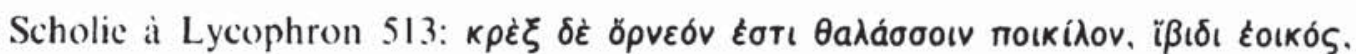

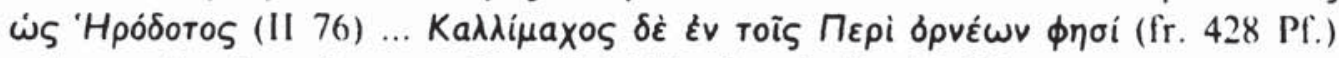

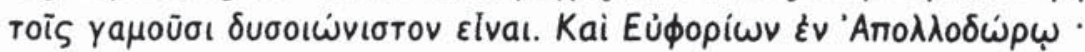

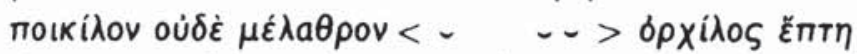

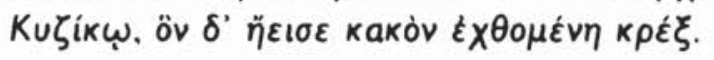

In his commentary on line 1, v. Groningen stated that Sitzler proposed to read $\mu \dot{\varepsilon} \lambda a \vartheta \rho o v$ (úr aï $a \lambda o v$ ). According to v. Groningen, however, the noun $\mu \varepsilon \dot{\lambda} a \vartheta$ pov has no need of two epithets. V. Groningen has failed to understand that Adjektivhäufung was a common feature of Hellenistic poetry: cf. W. Bühler, die Europa Des Moschos, Wiesbaden 1960 , p. 212 ff. and my commentary on Theocritus' Idyll XXIV (Amsterdam 1979), p. 37.

Fr. 11

$$
\begin{aligned}
& \text { ーテーテーテーテー ง }
\end{aligned}
$$

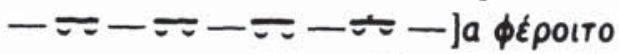

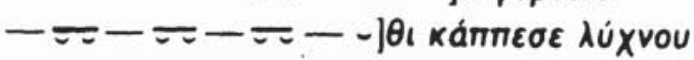




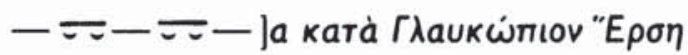

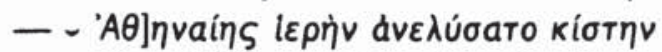

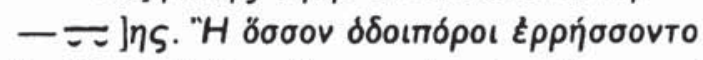

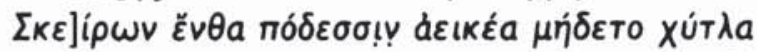

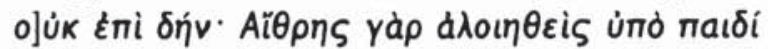

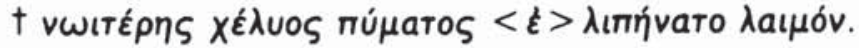

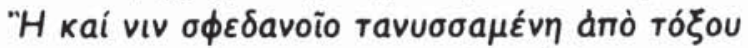

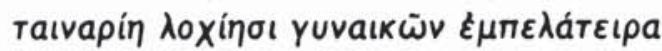

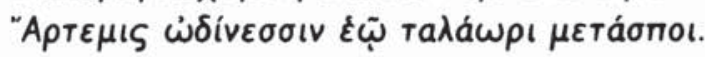

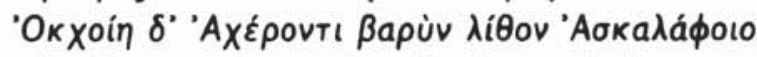

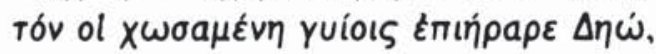

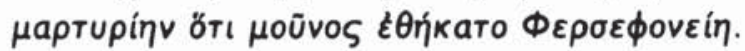

Translation by D. L. Page (Select Papyri, vol. III, Loeb edition, London 1950, reprint, p. 493 ff.): "(v. 4 sqq.) ... to Hersa at the Glaucopium, because she opened the sacred coffer of Athene: or as wanderers were dashed to pieces, where Sciron invented an unnatural washing for his feet, but not for long: crushed by the son of Acthra, he was himself the last to fatten the gullet of our tortoise: or may Taenarian Artemis, who comes to women in their pangs of travail, stretch her violent bow and reach him with her shaft therefrom: and on the Acheron may he bear the heavy boulder of Ascalaphus, which Demeter in her anger fastened upon his limbs, hecause he alone bore witness against Persephone..."

In line 11 Artemis is given the epithet raıvapin. Page considered that

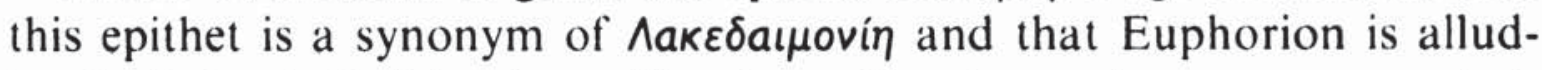
ing to Artemis Orthia. According to v. Groningen, however, ralvapin is

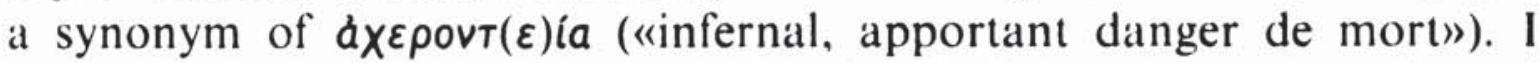
would like to suggest that Euphorion is alluding to the connection of Artemis with Hecate, a goddess who was concerned with the under-

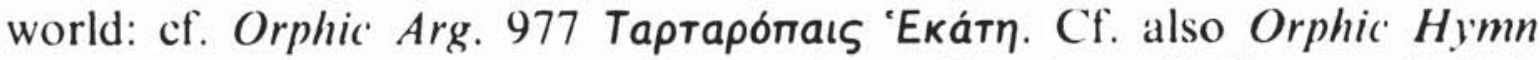
36, 9 where Artemis has the epithet X Yovia. For Artemis-Hecate cf. Callimachus, fr. 461 (Pfeiffer).

In his commentary on line 15, v. Groningen noted that the form

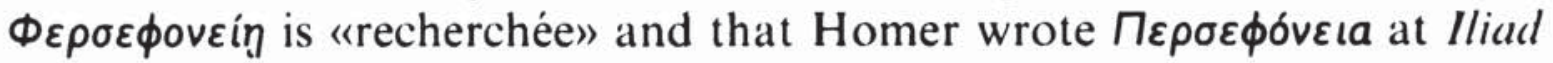
IX 457. V. Groningen failed to notice that $Ф \varepsilon \rho \sigma \varepsilon \phi o ́ v \varepsilon \varepsilon a$ is attested as a Homeric variant reading: cf. I. La Roche, Homeri Ilias, Leipzig 1873, vol. I. p. 261. For the tendency of Hellenistic poets to reproduce Homeric variant readings of. G. Giangrande, Scripta Minora Alexandrina, Amsterdam 1980, vol. I, p. 294. Euphorion employed Homeric

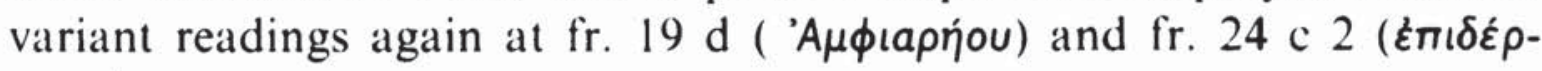
кETal). 
Fr. 13

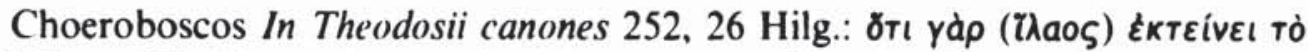

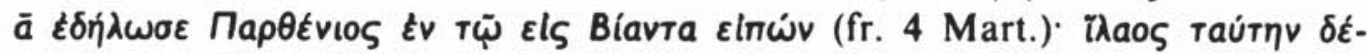

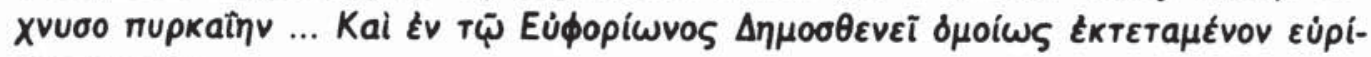
бKETal olov.

Saípovos liáoio.

Commenting on this fragment v. Groningen stated that the same

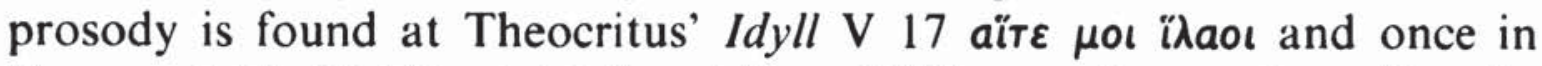

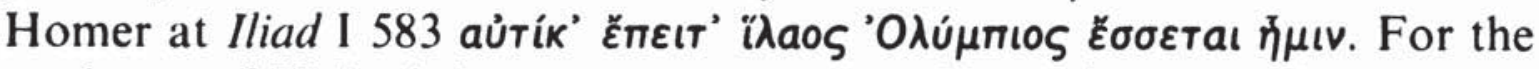
tendency of Hellenistic poets to reproduce Homeric unica $\mathrm{cf}$. G. Giangrande, Scripta Minora Alexandrina, vol. I, p. 293.

Fr. 15

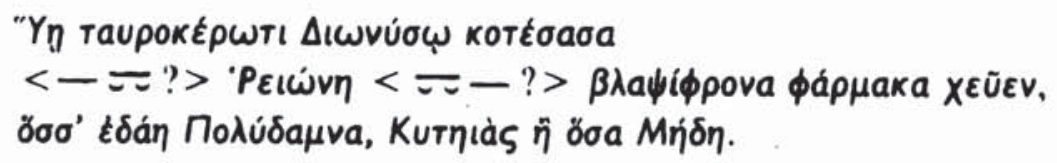

This fragment concerns Dionysus. V. Groningen was puzzled by the

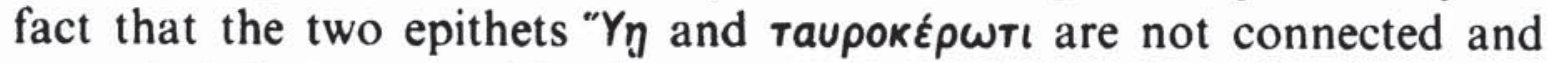

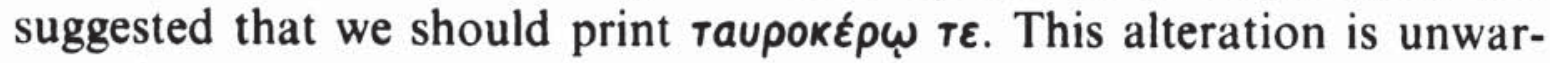
ranted. V. Groningen failed to understand that asyndeton between adjectives is common in Hellenistic poetry: cf. Bühler, op. cit., p. $212 \mathrm{ff}$., and Lapp, op. cit., p. $80 \mathrm{f}$.

In his commentary on the aorist ż́án in line 3, v. Groningen stated that one might have expected to find the perfect or pluperfect tense. I would like to point out that the aorist could have a pluperfect meaning: cf. my commentary on Theocritus' Idyll XXIV, p. 32.

Fr. 19 e

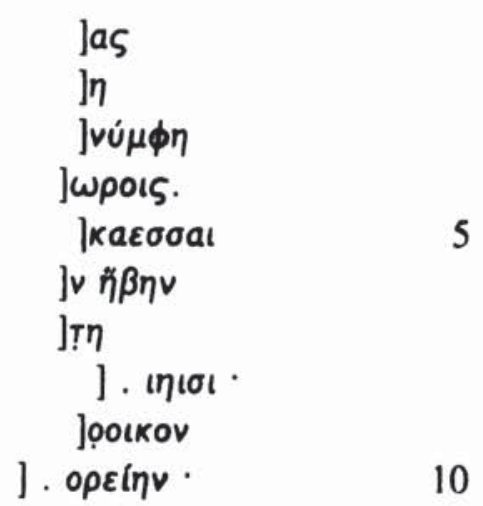




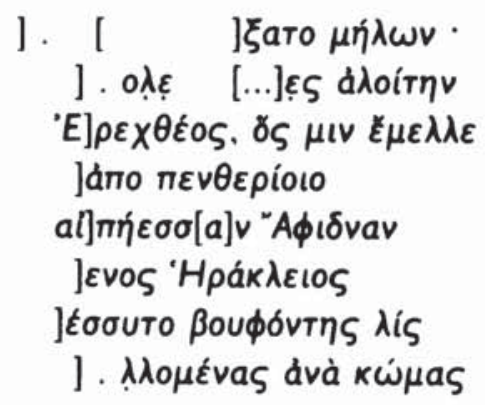

V. Groningen commented as follows on line 5: «Barigazzi dit, à

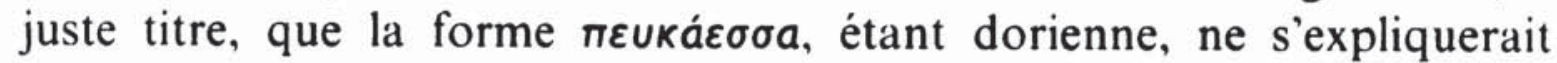
pas». It should be noted, however, that Doric forms were regularly employed in Hellenistic epic poetry: cf. G. Giangrande, Scripta Minora Alexandrina, vol. I, pp. 65 ff. and 292 f.: «Homer's language was a mixture of dialects: the background was Ionic, but there was an infusion of Doric and Attic elements. Apollonius deliberately reproduced such a mixture in his own poem». Cf. also v. Groningen's comments on p. 95,

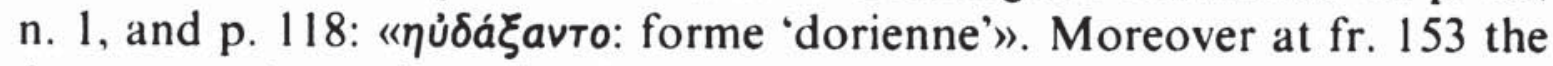
form vavayóv need not be altered.

Fr. 22

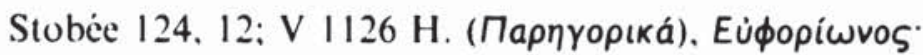

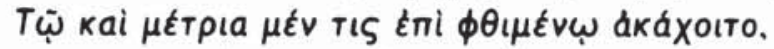

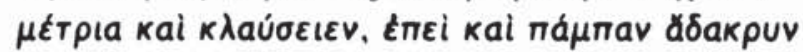

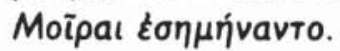

Commenting on this fragment, v. Groningen (op. cit., p. 91) suggested that since no pronoun is expressed in these lines we might understand that the second person is intended. I would like to add that the omission of the personal pronoun is a Homerism: cf. my New' Essays In Hellenistic Poetry, Amsterdam 1985, p. 83.

Fr. 24 a

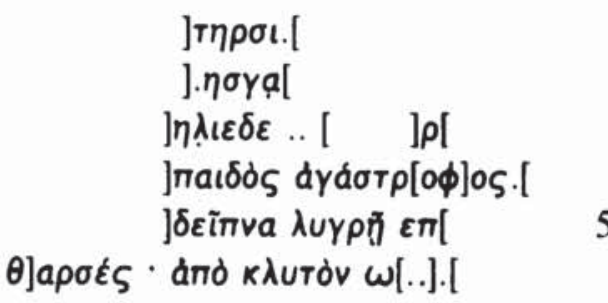




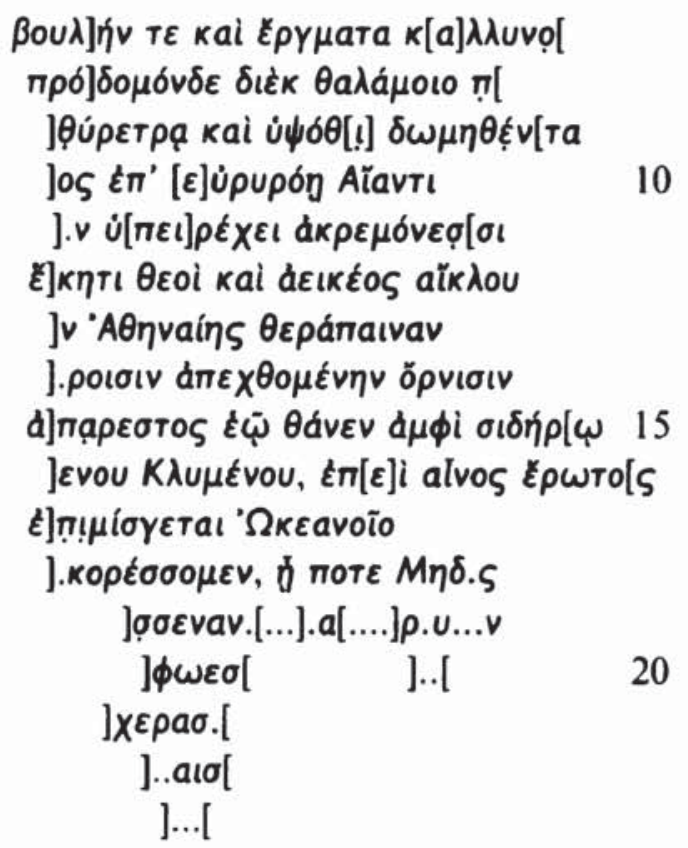

This fragment is from Euphorion's $\Theta \rho \not ̣ \xi$. V. Groningen commented

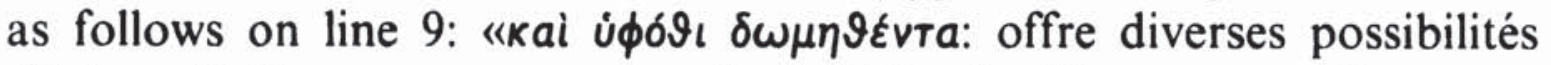
d'interpretation: a. comme seconde epithète de Эúpetpa, ce qui ne convient guère; b. 'nachgestelltes kaî' (Latte); ce serait vraiment unique». It should be noted here that kai postpositum is well attested in Hellenistic poetry: cf. A.S.F. Gow, Theocritus, Cambridge 1965, reprint, vol. II, p. 175, and G. Giangrande, Apophoreta Philologica M. Fernández-Galiano, Madrid 1984, vol. I, p. 368. Cf. also my New Studies In Greek Poetry, Amsterdam 1989, p. 53.

Fr. 24 c I

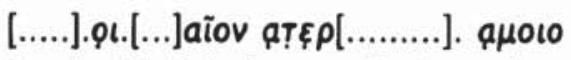

$[\ldots ..] \gamma d \phi u[\sigma] \sigma d \mu \varepsilon v o \varsigma$ $\beta o \rho[\ldots . . . ..] \gamma \varepsilon \ldots . . \theta \omega$.

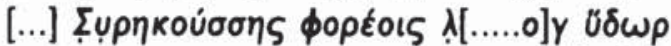

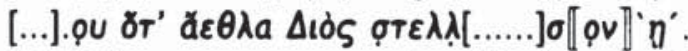

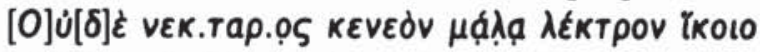

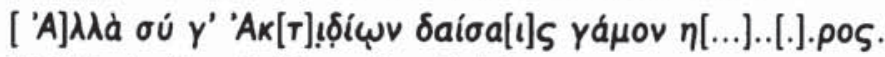

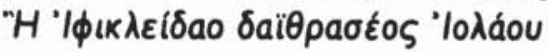

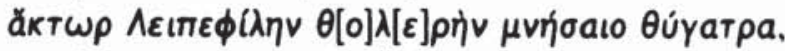

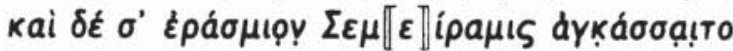

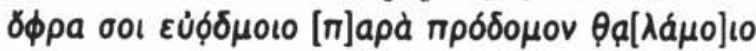

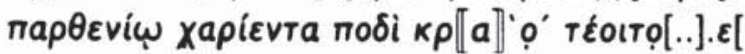

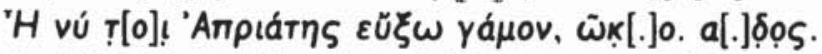

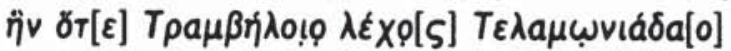

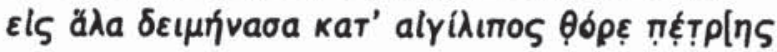

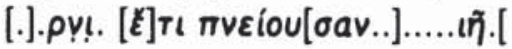




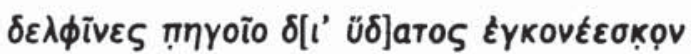

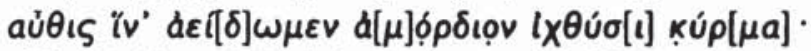

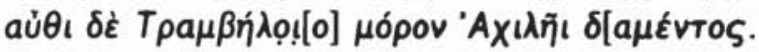

Translation by Page (op. cit., p. 495 ff.): «"... may you come to a... bed. Go, celebrate a wedding with... or like Actor woo some fair Leipephile, daughter of Iolaus the warrior son of Iphicles. Or may a Semiramis embrace you, her pretty husband, that on the threshold of her fragant boudoir she may trample the corpse of her charming bridegroom. Now, shameless wretch, a new sort of wedding will I make for Apriate!" She spoke; and for terror of the bed of Trambelus, son of Telamon, leapt from a steep rock into the sea. And... dolphins hastened through the dark waters (to rescue) her still alive; that we might sing hereafter... and hereafter the fate of Trambelus, vanquished by Achilles...»

This fragment concerns Apriate and Trambelus. V. Groningen com-

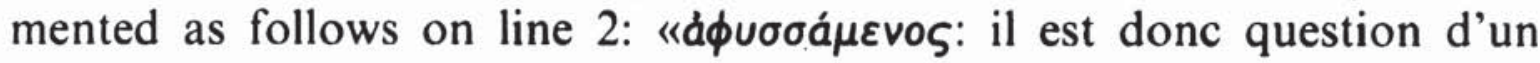
sujet masculin.» I would like to add that participles were sometimes treated as having two terminations only: cf. Gow, Theocritus, vol. II, p. 297.

In his commentary on line $16, v$. Groningen stated that Euphorion

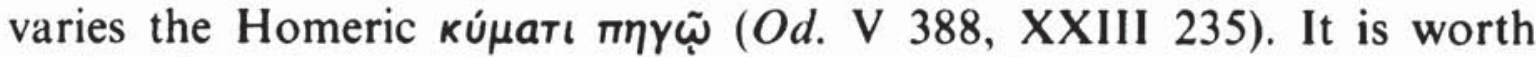
noting that the poet has purposely reversed the Homeric word-order. For other examples of imitatio cum uariatione cf. G. Giangrande, Scripta Minora Alexandrina, vol. I, p. 296.

At line 17 Euphorion has used the Attic form aúgıৎ which is attested as a Homeric variant reading. For the employment of Attic forms in Hellenistic epic verse cf. G. Chryssafis, A Textual And Stylistic Commentary On Theocritus' Idyll XXV, Amsterdam 1981, p. 119, and my New Studies In Greek Poetry, p. 46.

Fr. 24 c 2

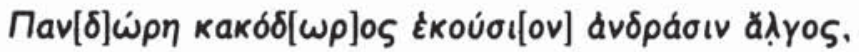

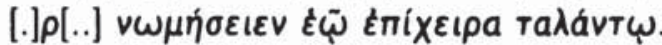

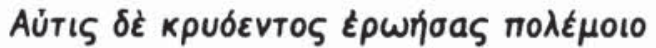

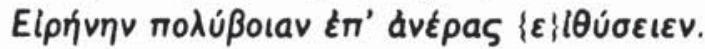

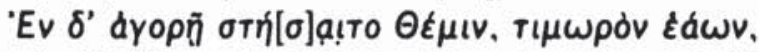

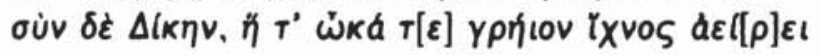

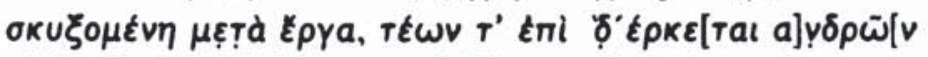

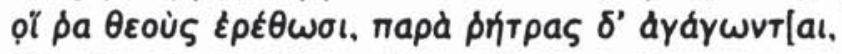

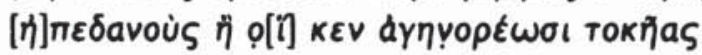

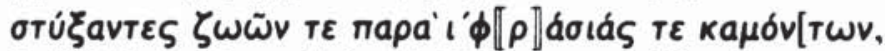

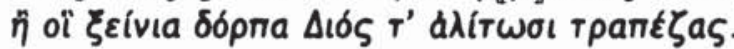

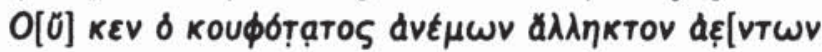




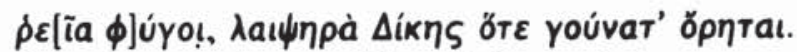

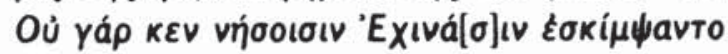

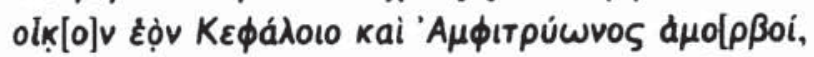

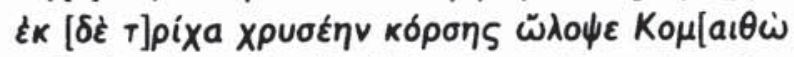

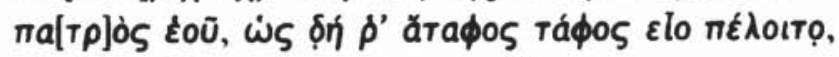

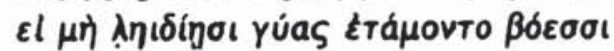

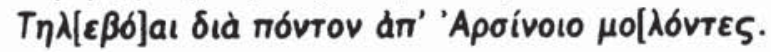

Translation by Page (op. cit., p. 497 ff.): «... Pandora, donor of evil, man's sorrow self-imposed. Ares allot them their wages in his scales, and rest again from chilling warfare, and send Peace with her Prosperity to men! And in the market let him set Themis up, requiter of good deeds: and, beside her, Justice, who leaps up like a tiger at once in anger at the deeds of men upon whom she looks

even them who provoke the gods and turn their commandments aside, and such as treat their feeble parents with arrogance, scorning the counsel of the living and the dead; or sin against the hospitable feast and the table of Zeus. The lightest of winds that blow unceasing could not easily escape the swift knees of Justice when up she leaps. Never in the islands Echinades had the companions of Cephalus and Amphitryon pressed on their vessel's..., nor had Comaetho cut the golden hair from her father's temple, that a wild beast might be her monstrous tomb - had nor the Teleboans cleft the field with stolen oxen, coming over the sea from Arsinus."

At line 47 Euphorion has employed the Homeric form aũtıs rather than the Atticism aú 9 เs which we find in fr. $24 \mathrm{c}$, line 17. For the tendency of Hellenistic poets to reproduce both alternative Homeric readings or forms cf. G. Giangrande, Scripta Minora Alexandrina, vol. I, p. $294 \mathrm{f}$.

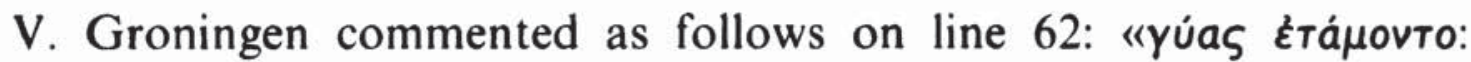
'labourer'; cf. Solon I, $47 \mathrm{D} \gamma \tilde{\eta} v \tau \varepsilon \dot{\varepsilon} \mu \omega v$. Le moyen s'explique». It is worth adding that the middle form of the verb is frequently employed by Hellenistic poets instead of the active: cf. my commentary on Theocritus' Idyll XXIV, p. 105 f. Cf. also v. Groningen's comments on pages

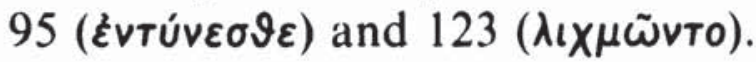

Fr. 25

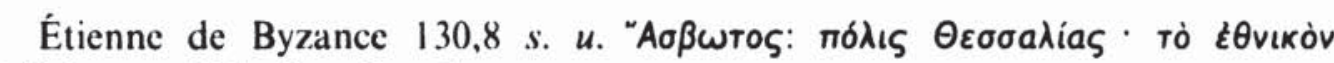

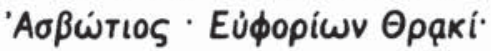

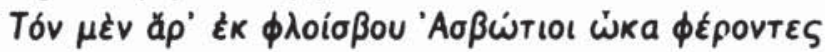

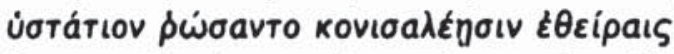

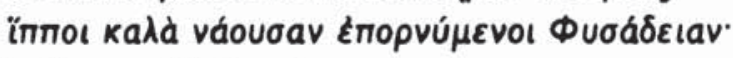

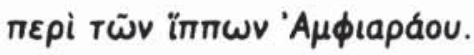

This fragment mentions the horses of Amphiaraus. The following

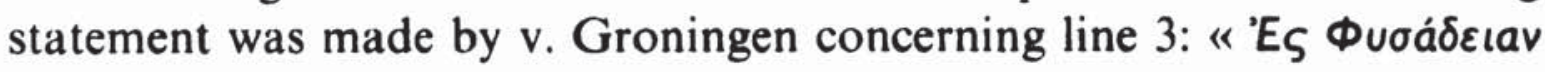


ne signifie rien d'autre que $\varepsilon_{\zeta}$ "Apyos; Euphorion évite l'indication banale. Le nom de n'importe quelle partie d'un pays peut remplacer chez lui le nom du pays même». For similar examples of metonymy in Hellenistic poetry cf. Lapp, op. cit., p. 22, and K. Alexander, A Stylistic Commentary On Phanocles And Related Texts, Amsterdam 1988, p. 111.

Fr. 29

Scholie à Clément d'Alexandrie, Protr. 27, II p. 308, 3 St.: 'mпокówv tis

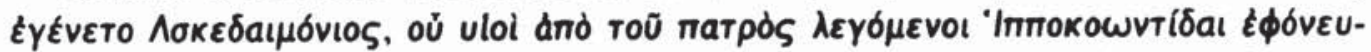

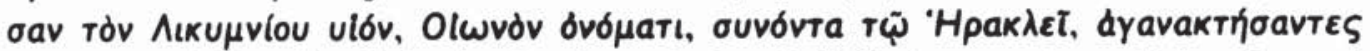

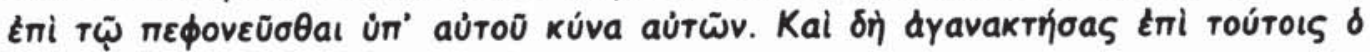
'Hрак

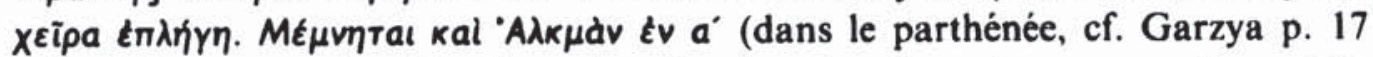

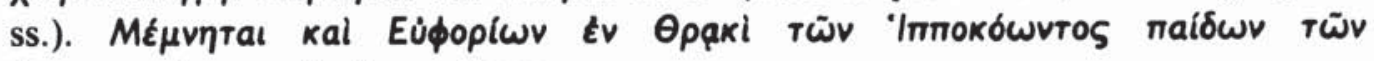

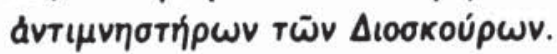

In his discussion of this fragment, v. Groningen noted that normally the Apharidae (i. e. Idas and Lynceus) are said to have sought to marry the Leucippides (cf. Teocritus' Idyll XXII). Here, however, Euphorion states that the sons of Hippocoon wanted to marry them. According to v. Groningen, «l'idée de considérer les Hippocoontides comme concurrents des Dioscures est conforme à la préférence d'Euphorion pour les traditions insolites». For the fact that Hellenistic poets often prefer to mention obscure versions of a myth cf. my Studies In The Poetry Of Nicander, p. 45. Cf. also v. Groningen's comments concerning fr. 77.

Fr. 30

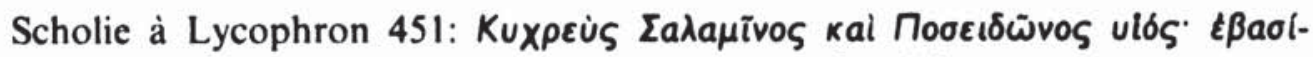

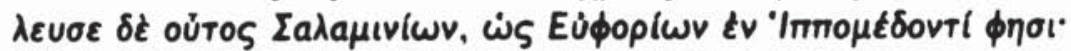

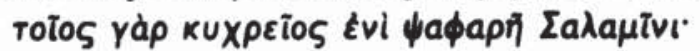

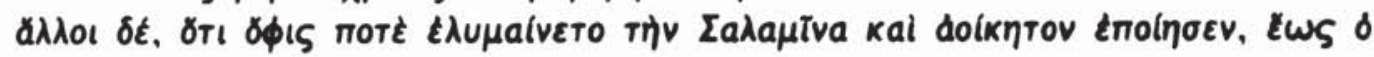

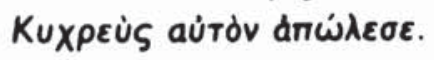

V. Groningen commented as follows on the word kuxpeĩos: «les manuscrits donnent en outre des variantes dont la seule intéressante est

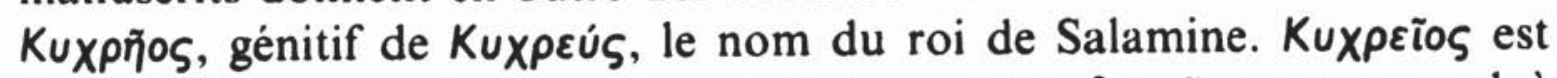

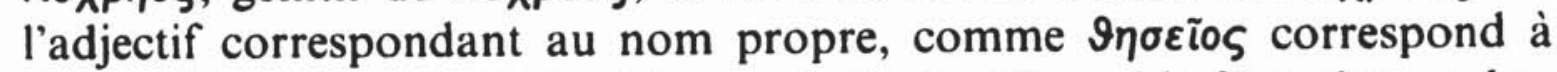

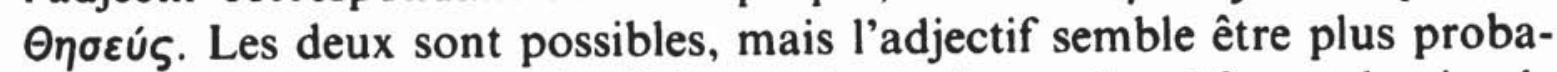
ble dans le contexte (voir ci-dessous) et plus recherché que le simple génitif et donc plus conforme aux habitudes du poète». It is worth adding that the adjective representing the genitive of a proper name is 
frequently found in Hellenistic poetry: cf. Gow, Theocritus, vol. II, p. 294. Cf. also Lapp, op. cit., p. $130 \mathrm{f}$.

Fr. 35

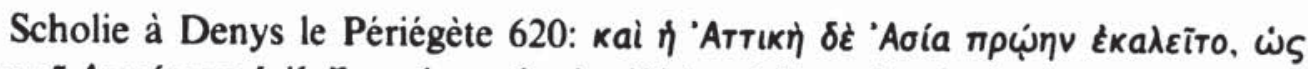

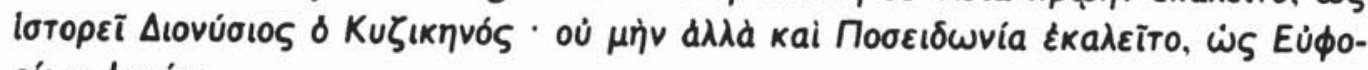

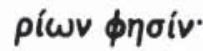

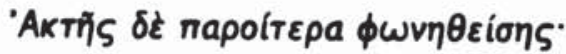

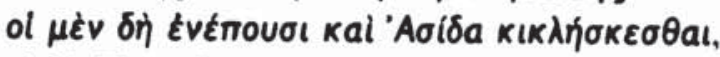

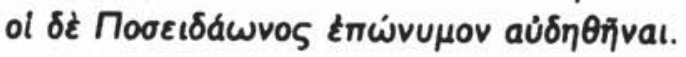

Commenting on this fragment, v. Groningen noted that Euphorion has composed three consecutive spondaic hexameters. For spondaic verses in Hellenistic poetry cf. my commentary on Theocritus' Idyll XXIV, p. 9, and Gow, Theocritus, vol. II, p. 239. V. Groningen also noted that Euphorion has employed three synonymous verbs. For the use of synonyms in hellenistic verse cf. my New Studies In Greek Poetry, pp. 45-46. Cf. moreover Lapp, op. cit., p. $116 \mathrm{f}$.

Fr. 37

Choeroboscos, Orthogr., dans Cramer Anecd. Oxon. 2, 239, 6: $\Lambda \varepsilon i n \omega \cdot \lambda \varepsilon \hat{\varepsilon \varepsilon \iota}$

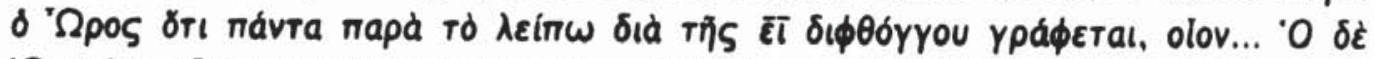

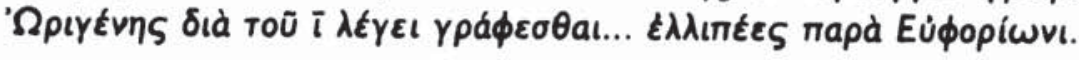

V. Groningen commented as follows: «Westerink, l. c., remarque

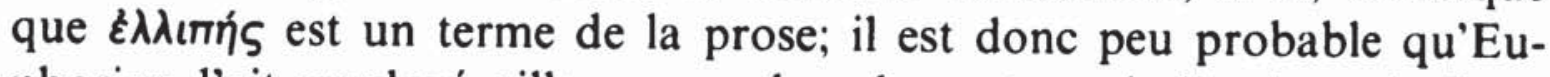
phorion l'ait employé ailleurs que dans le contexte indiqué par le fragment précédent, c'est-à-dire dans la Mopsopia». It is worth remembering that «Hellenistic poets employed many prosaic words, meanings of words and syntactical constructions»: cf. G. Giangrande, Scripta Minora Alexandrina, vol. II, p. 391.

Fr. $38 \mathrm{a}$ et $\mathrm{b}$

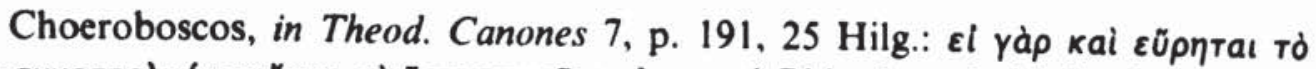

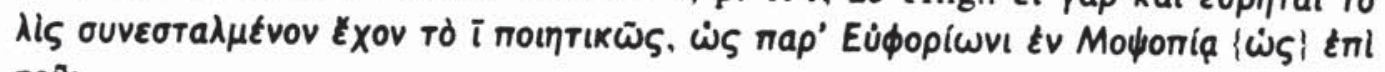
TOO.

ral ná̀ıv.

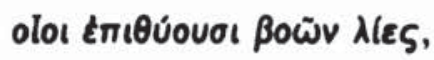

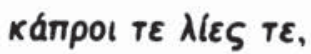

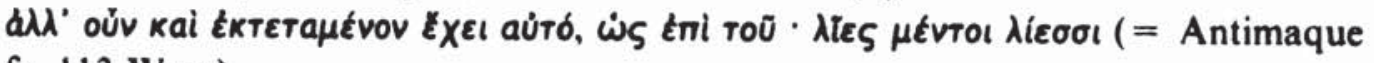
fr. 113 Wyss). 
V. Groningen noted that Meineke proposed the alteration of $\delta^{\prime}$

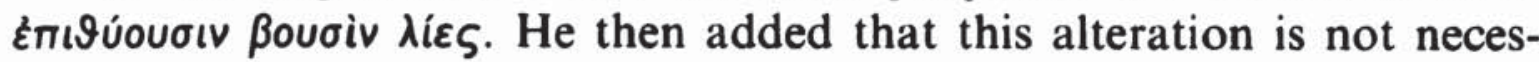
sary because «le génitif est normal pour indiquer le but, la direction d'un mouvement». For other examples of this use of the genitive cf. G. Giangrande, L'Ant. Classique, 1986, p. 310, and Kühner-Gerth, vol. I, p. 351 .

Fr. 40

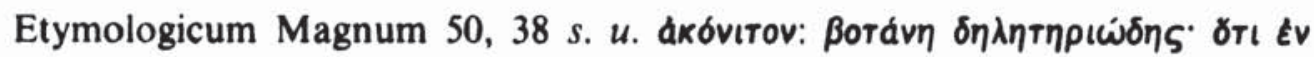

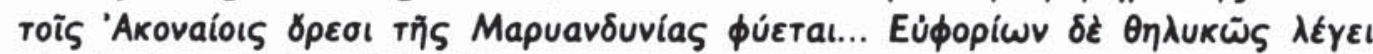

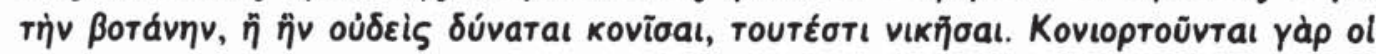

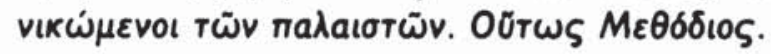

V. Groningen commented as follows: «Ceci nous apprend que, dans ce poème, Euphorion ne disait pas, comme tout le monde, tó axóvitov,

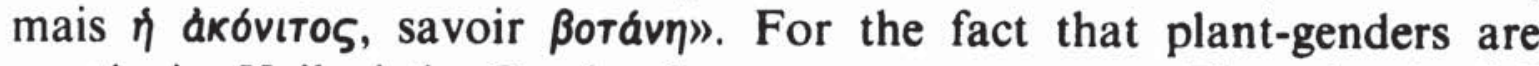
erratic in Hellenistic Greek cf. my commentary on Theocritus' Idyll XXIV, p. 85.

Fr. 44

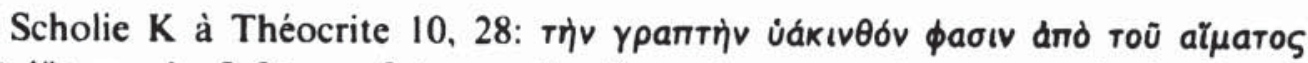

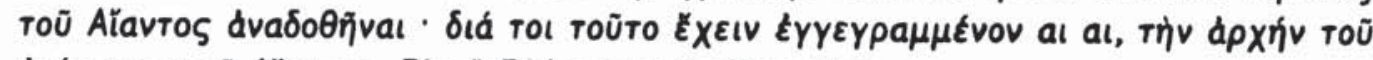

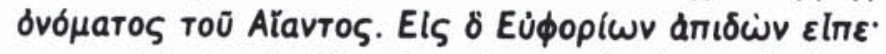

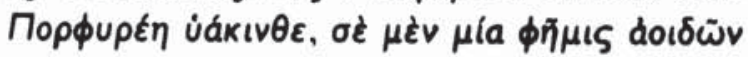

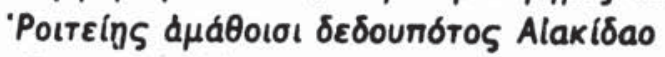

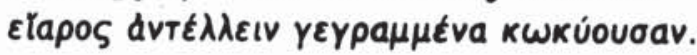

line 2 'Poiteings Brubach: 'Poireiols UA

In line 2 v. Groningen printed Brubach's alteration 'Poıreins. There is, however, no need for us to alter the mss. reading Poirelois. The poet has obviously restricted the adjective to two terminations: cf. my Studies In The Poetry Of Nicander, p. 16. Similarly at fr. 193 e Euphorion may have restricted the adjective 'Aóvios to two terminations: cf. v. Groningen's comments on p. 242.

In his commentary on line 3, v. Groningen stated that the noun Elapos may mean either 'blood' or 'spring' in this passage. The reader should note that such ambiguity is typical of Hellenistic poetry: cf. my Studies In Theocritus And Other Hellenistic Poets, p. 37 f., and my New Studies In Greek Poetry, p. 42. 
Fr. 48

Stobée 59, 16, IV $403 \mathrm{H}$. (mepi vautidíns kai vavayiou), Eüфopíwvos Фiגoktítou:

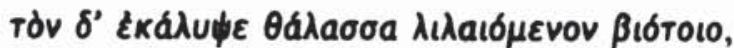

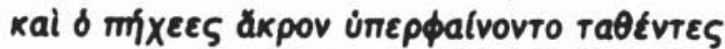

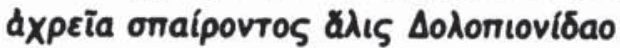

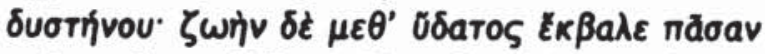

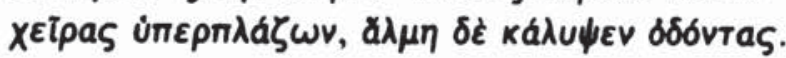

V. Groningen made the following observation concerning the verb

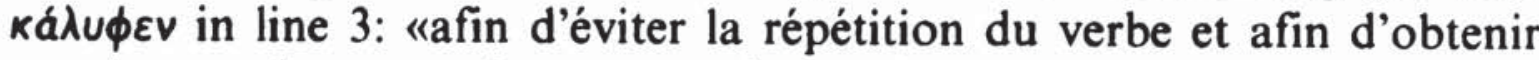
une image plus normale on a voulu corriger; Sitzler propose $\varepsilon_{k} \lambda u \sigma \sigma \varepsilon v$,

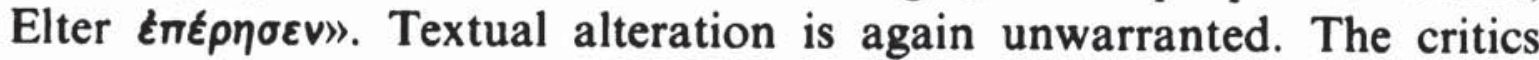
have failed to understand that repetition is a common feature of Hellenistic poetry: cf. my commentary on Theocritus' Idyll XXIV, p. 106, and Lapp, op. cit., p. $54 \mathrm{ff}$. For repetition in Euphorion cf. fr. 22

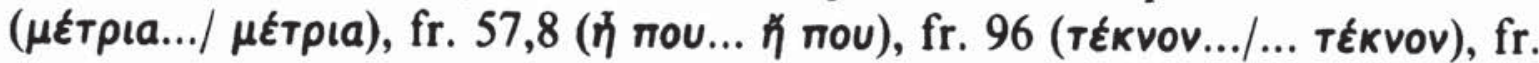

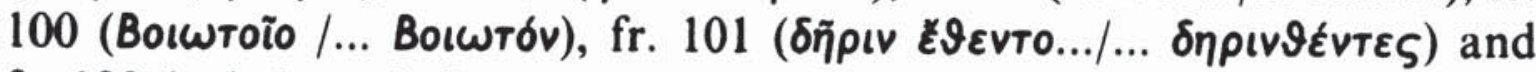

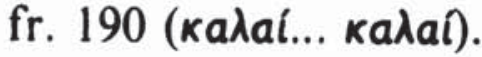

Fr. 57

$$
\begin{aligned}
& \text { a!n़ा } \\
& \text { לavods } \$ 1 \\
& \text { kai ol } \delta \varepsilon i \mu a \text { ivovт [l }
\end{aligned}
$$

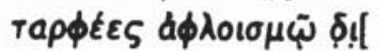

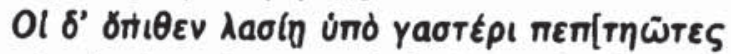

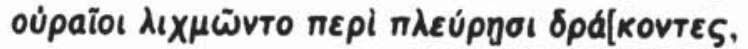

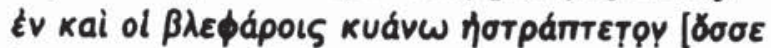

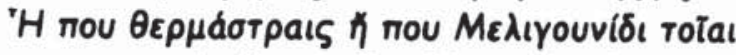

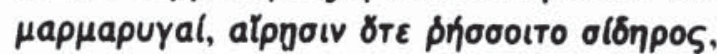

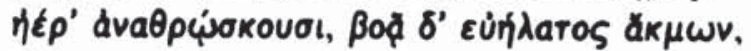

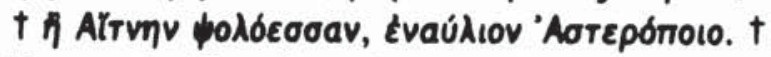

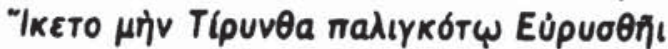

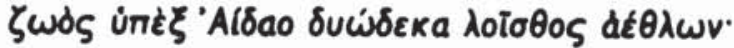

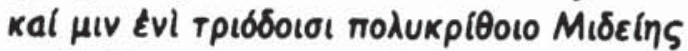

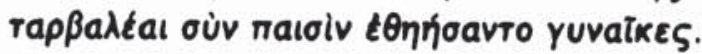

Translation by Page (op. cit., p. 493): «Behind, under his shaggy belly cowering, the serpents that were his tail darted their tongues about his ribs. Within his eyes, a beam flashed darkly. Truly in the Forges or in Meligunis leap such sparks into the air, when iron is beaten with hammers, and the anvil roars beneath mighty blows, $\ldots$ or up inside smoky Etna, lair of Asteropus. Still, he came alive to Tiryns out of Hades, the last of twelve labours, for the pleasure of malignant Eurystheus; and at the crossways of Mideia, rich in barley, trembling women with their children looked upon him..." 
This fragment describes how Heracles brought Cerberus from hades to Tiryns. Cerberus is said in line 6 to have a tail which consists of ser-

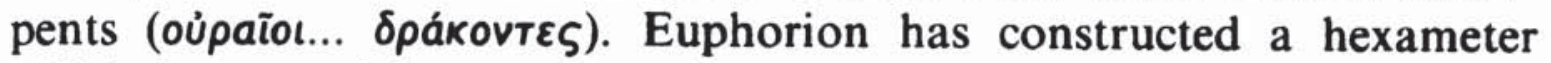
which is encased by an adjective and a noun in agreement: cf. G. R. McLennan, Callimachus, Hymn to Zeus, Rome 1977, p. 97, for other examples of this stylistic device.

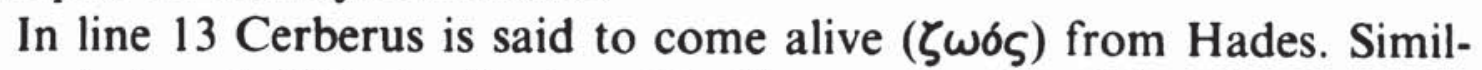
arly at Arg. I 126 Apollonius Rhodius states that Heracles brought

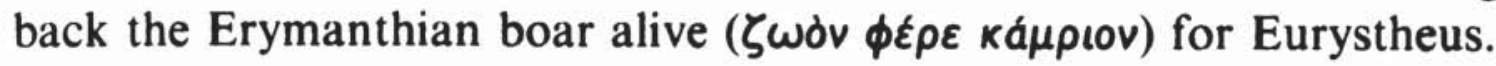

Fr. 59

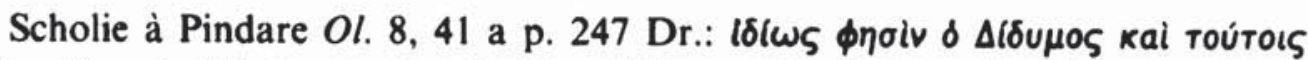

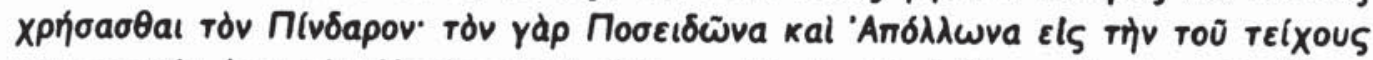

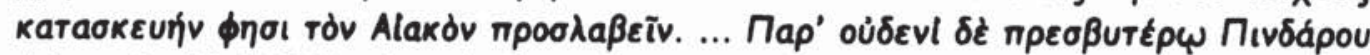

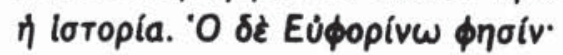

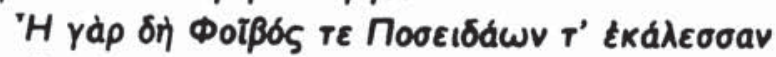

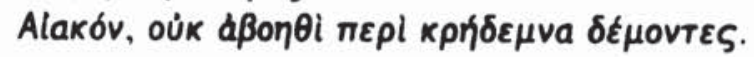

V. Groningen commented as follows on line 1: " 'H $\gamma$ à $\delta \dot{\eta}$ : Denni-

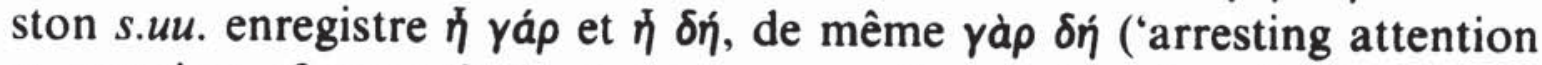
at opening of narrative'), mais non pas la combination $\eta \gamma$ ya $\rho \delta \eta$. Le sens est clair: c'est un $\gamma d \dot{\alpha} \rho$ ó renforcé». It should be noted that the combination $\eta \dot{y}$ à $\delta \dot{\eta}$ occurs in the same metrical sedes at Moschus, Europa, line 74, and Manetho, II 64.

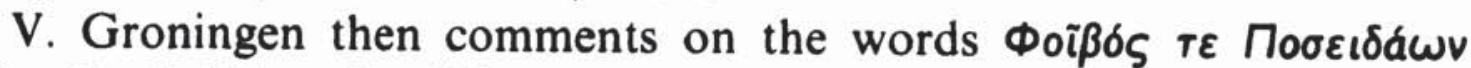
$T(\varepsilon)$ : «En $\Phi 441$ ss. Poséidon rapelle à Apollon qu'ils ont dû servir Laomédon, lui, en bâtissant les remparts de Troie, Apollon, en gardant les troupeaux; mais en 452 s. les deux dieux sont occupés à construire les murs». For another case where a poet has deliberately alluded to two different versions of the same myth cf. my New Studies In Greek Poetry, p. 67. Cf. also fr. 120 where Euphorion is said to have stated that Pelops was both Lydian and Paphlagonian:

Scholie à Apollonios de Rhodes 2, 358 s. (Pélops, roi des Paphlagoniens):

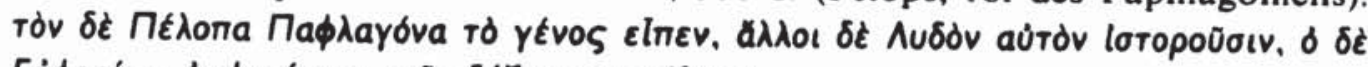

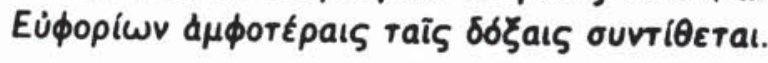

Fr. 62

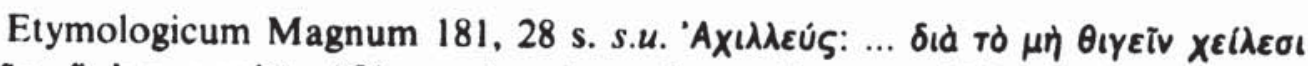

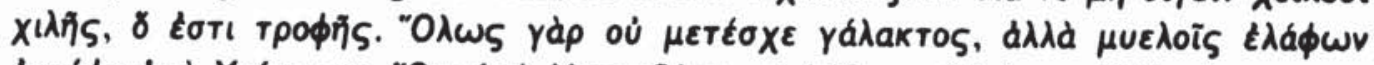

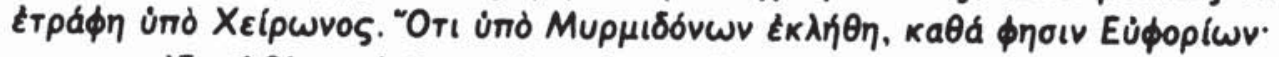

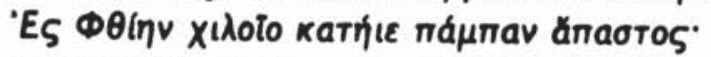

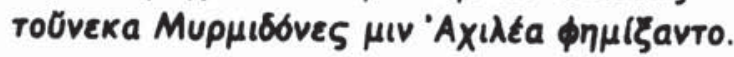


This fragment explains how Achilles got his name. Euphorion has

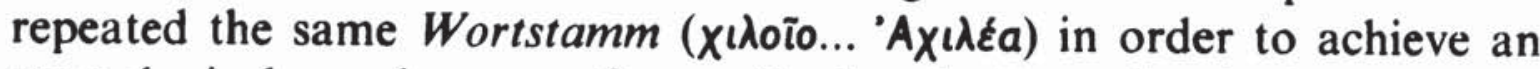
etymological word-game: cf. my Studies In Late Greek Epic Poetry,

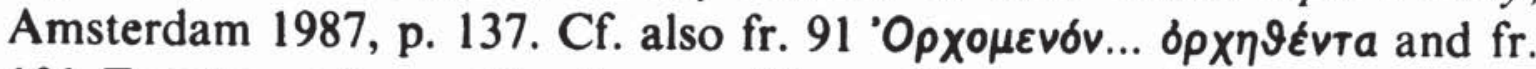
$191 \Pi \varepsilon \rho \sigma \eta \tilde{a} . . . \pi \varepsilon \rho \sigma \varepsilon$. For the repetition of the same Wortstamm cf. my New Studies In Greek Poetry, p. 40.

Fr. 63

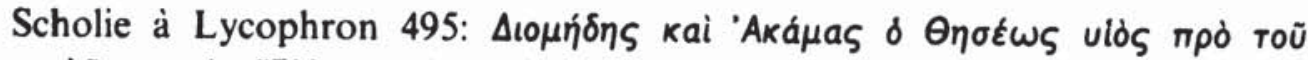

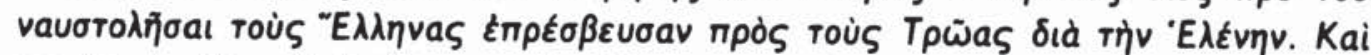

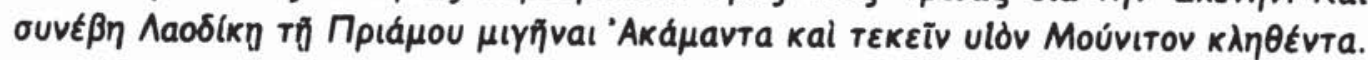

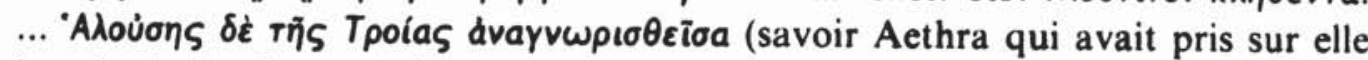

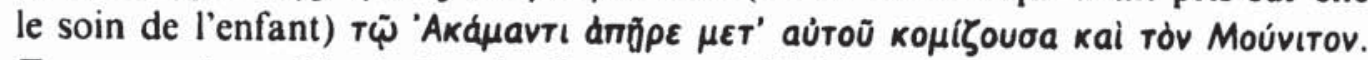

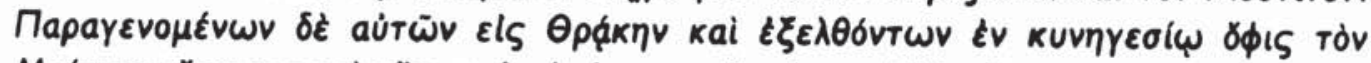

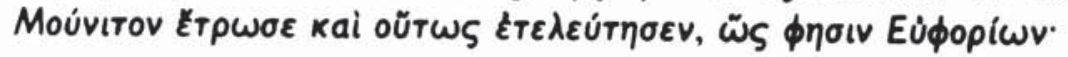

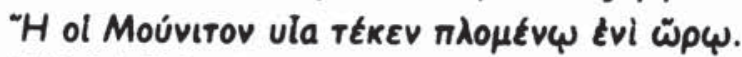

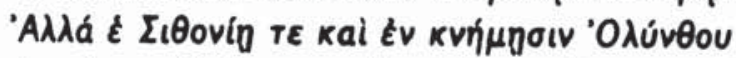

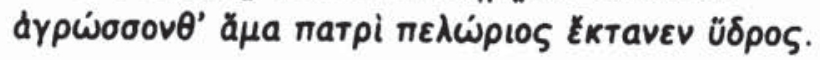

V. Groningen was puzzled by the fact that Olynthus is mentioned together with Sithonia in line 2 and stated that this is «une nouvelle preuve du peu de précision des indications topographiques d'Euphorion". It should be noted, however, that a connection between these two places is attested elsewhere: cf. Thes. Gr. Ling., s.u. "Oגuv९os:

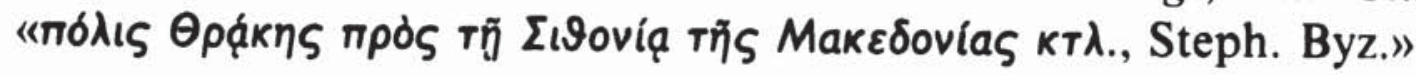

Fr. 85

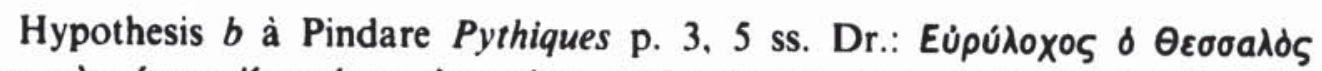

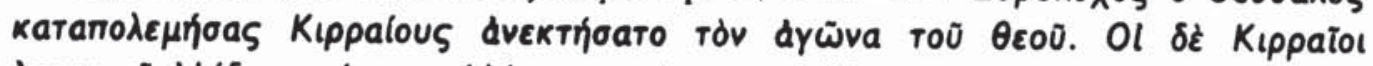

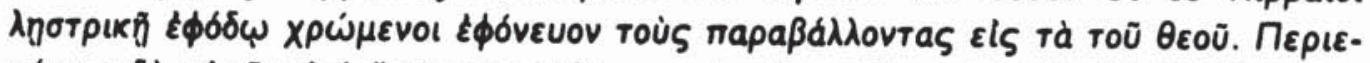

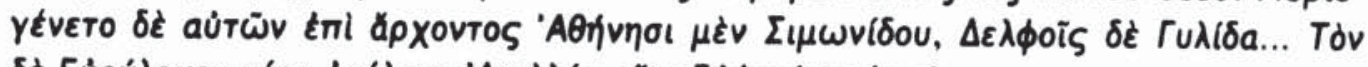

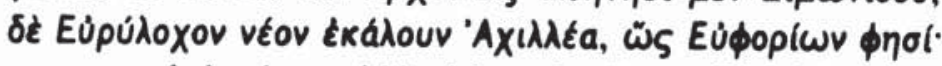

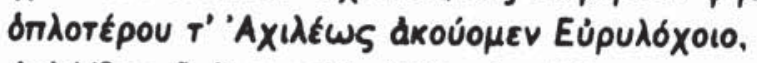

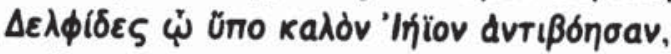

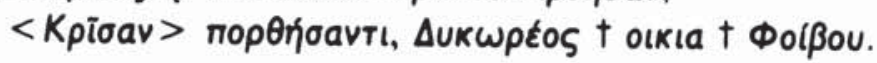

In his discussion of this fragment, v. Groningen stated that Koĩav "est une excellente conjecture de Boeckh». He was, however, puzzled by the phrase Aukwpźos olkía Фoißou and commented as follows: «Mais est-il admissible que Crisa, ce repaire de bandits impies, ait été appelé 'demeure du Phoebus delphique'?" V. Groningen has forgotten that 
there was a temple of Apollo at Crisa: cf. Homeric Hymn to Apollo, lines 269 and $438 \mathrm{ff}$.

Fr. 90

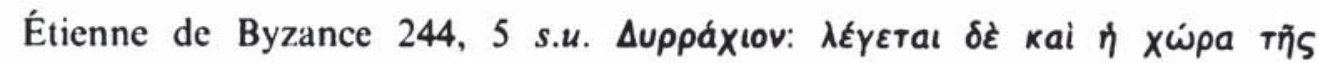

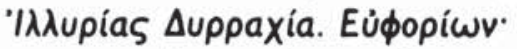

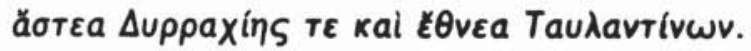

V. Groningen commented on this fragment as follows: «Le pluriel

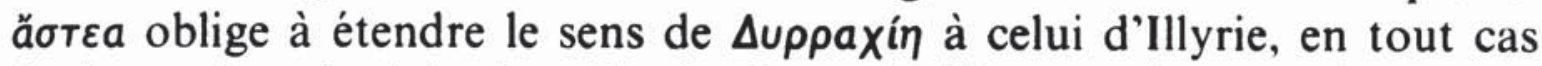

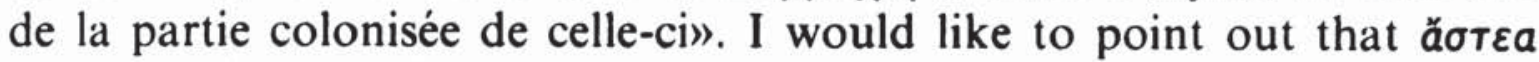
may also be regarded as a poetic plural; cf. my Studies In The Poetry

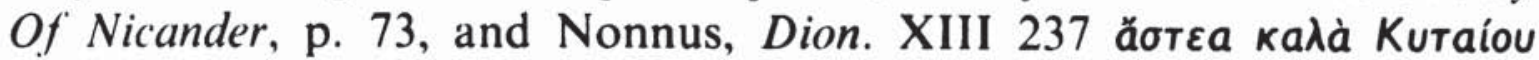
(«the fair city of Cytaion»). For another poetic plural in Euphorion cf.

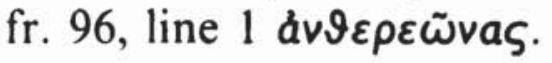

Fr. 123

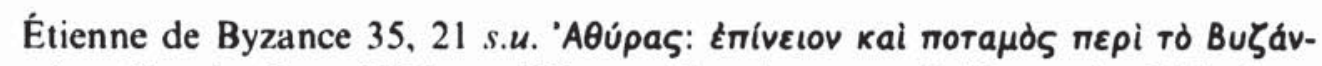

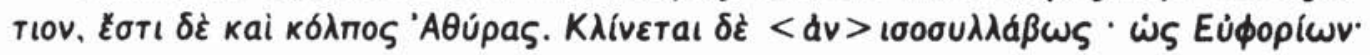

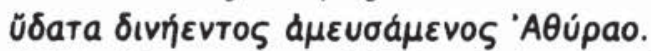

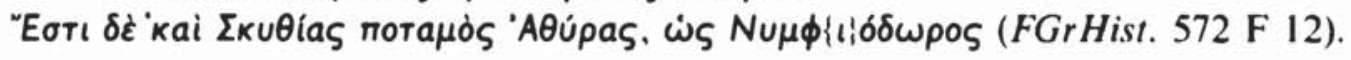

The following observation was made by v. Groningen concerning

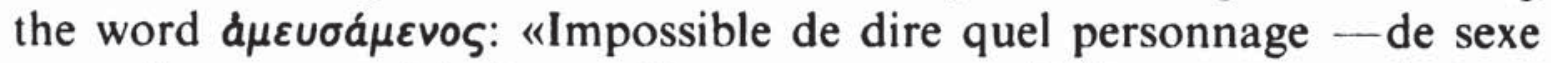
masculin - a passé le fleuve. On notera encore l'allongement amétrique de la dernière syllabe du participe». It is worth noting that similar metrical lengthenings ${ }^{3}$ are to be found in Theocritus: cf. Chryssafis, op. cit., p. 29.

Fr. 131

Col. I ] ] ] ] Jạ äגıs карфоіато поїа

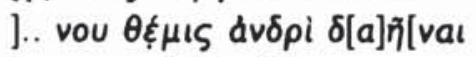

J

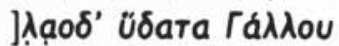

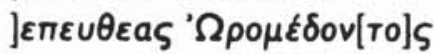

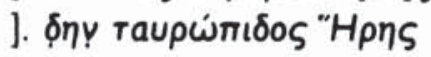

${ }^{3}$ For metrical lengthening in Euphorion cf. also De Cuenca, op. cit., p. 44. 


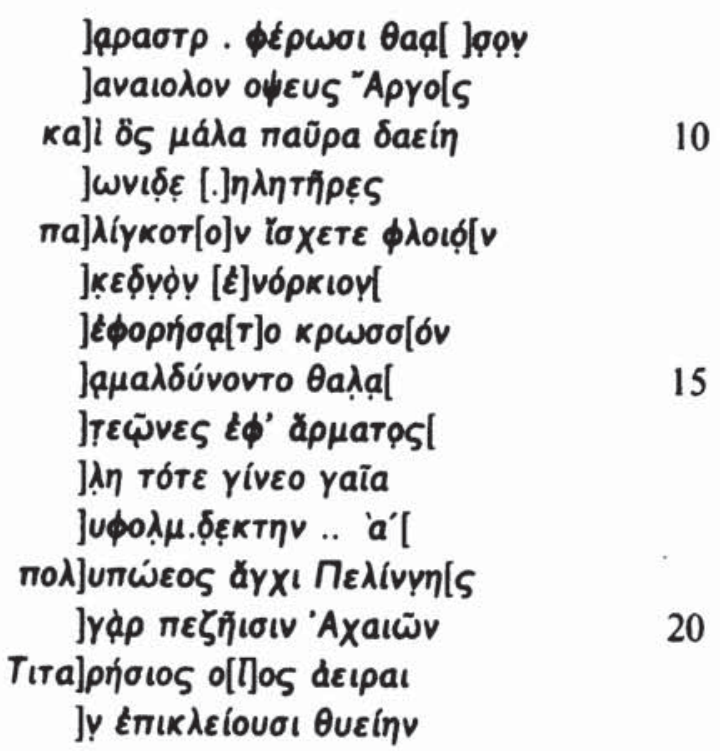

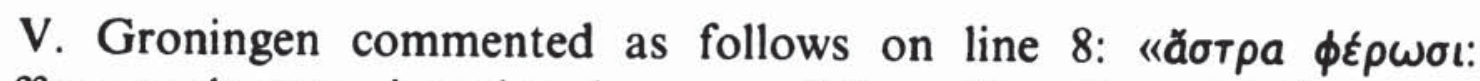
n'offre pas de sens, à moins de songer à la voûte céleste (?); le neutre ne peut être le sujet d'un verbe au pluriel». It should be noted, however, that the use of a plural verb with a neuter plural subject is well attested in Hellenistic poetry: cf. Gow, Theocritus, vol. II, p. 55, and Callimachus, fr. 75,16 (Pfeiffer). Cf. moreover v. Groningen's note on fr. 193 f.,

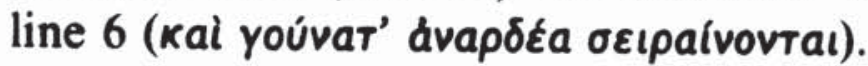

The following observation was made by v. Groningen concerning the verb a $\mu a \lambda \delta$ úvovto in line 15: "L'imparfait indique une habitude, ou bien il se situe dans une partie descriptive du récit». It is also possible that the poet used the imperfect instead of the aorist: cf. Gow, Theocritus, vol. II, p. 83, and my New'Studies In Greek Poetry, p. 106.

Fr. $193 \mathrm{e}$
]'Aovio[t]o nepaíns

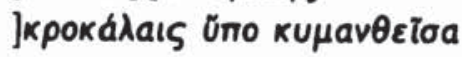

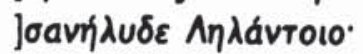

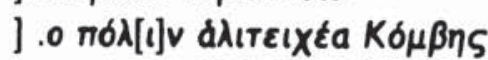

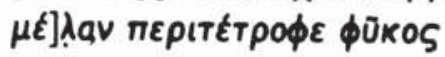

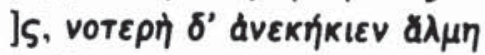

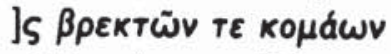

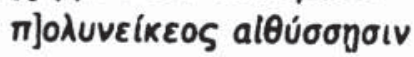

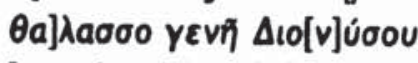
]aтa
10

V. Groningen was puzzled by line 6 and commented as follows:

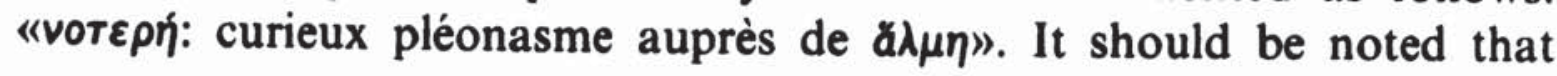


such pleonasms are quite common in Hellenistic poetry: cf. Lapp, op. cit., p. 70, quoting e.g. Callimachus, Hymn IV 211 vótıos... ह̌ $\rho \rho \varepsilon \varepsilon v$

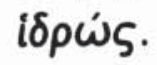

Fr. $193 \mathrm{f}$

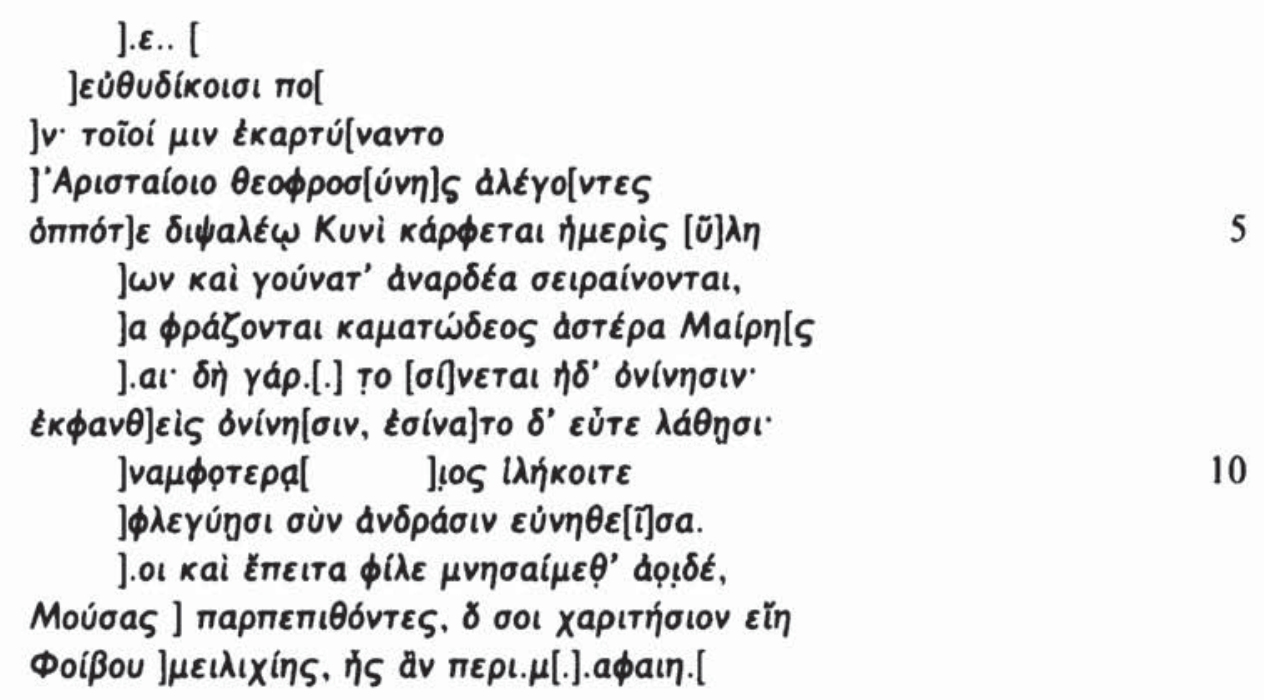

In his commentary on line $11, \mathrm{v}$. Groningen noted that Lobel thought that there are references in this line to the Phlegyae and to Macelo, the mother of Dexithea. However Lobel could not understand "how all the details to which allusions seem to be discernible could be crushed into these two verses". I would like to point out that Hellenistic poets, when narrating a well-known legend, were usually allusive: $\mathrm{cf}$. my Studies In Theocritus And Other Hellenistic Poets, p. 68. In other words, Euphorion need not have mentioned all the details of the legends concerning Macelo and the Phlegyae in this passage. Cf. moreover v. Groningen's comments on p. 88 («Euphorion aime les allusions passagères») and p. 90 ("Le poème a été riche, semble-t-il, en allusions compactes et passagères à des mythes divers»).

HeATHER White 